\title{
Genetic polymorphisms in neuroendocrine disorder-related candidate genes associated with pre-pregnancy obesity in gestational diabetes mellitus patients by using a stratification approach
}

\author{
Kai Wei Lee ${ }^{1} \wedge$, Siew Mooi Ching ${ }^{1,2,3} \wedge$, Navin Kumar Devaraj ${ }^{1,2} \wedge$, Fan Kee Hoo ${ }^{4} \wedge$ \\ ${ }^{1}$ Department of Family Medicine, Faculty of Medicine and Health Sciences, Universiti Putra Malaysia, Serdang, Selangor, Malaysia; ${ }^{2}$ Malaysian \\ Research Institute on Ageing, Universiti Putra Malaysia, Serdang, Selangor, Malaysia; ${ }^{3}$ Department of Medical Sciences, School of Healthcare and \\ Medical Sciences, Sunway University, Bandar Sunway, Malaysia; ${ }^{4}$ Department of Medicine, Faculty of Medicine and Health Sciences, Universiti \\ Putra Malaysia, Serdang, Selangor, Malaysia \\ Contributions: (I) Conception and design: KW Lee, SM Ching; (II) Administrative support: NK Devaraj; (III) Provision of study materials or patients: \\ FK Hoo; (IV) Collection and assembly of data: KW Lee, SM Ching, FK Hoo; (V) Data analysis and interpretation: All authors; (VI) Manuscript \\ writing: All authors; (VII) Final approval of manuscript: All authors. \\ Correspondence to: Siew Mooi Ching. Department of Family Medicine, Faculty of Medicine \& Health Sciences, Universiti Putra Malaysia, 43400, \\ Serdang, Selangor, Malaysia. Email: sm_ching@upm.edu.my.
}

Background: Certain candidate genes have been associated with obesity. The goal of this study is to determine the association between thirteen neuroendocrine disorder-related candidate genes and prepregnancy obesity among gestational diabetes mellitus (GDM) patients using the stratification approach defined the Asian and International criteria-based body mass index (BMI).

Methods: This was a post-hoc case-control exploratory sub-analysis of a cross-sectional study among GDM women to determine which candidate single nucleotide polymorphisms (SNPs) related to neuroendocrine disorders may be associated with obesity. Factors were adjusted for socio-demographic characteristics and concurrent medical problems in this particular population. Pre-pregnancy BMI and concurrent medical profiles were obtained from maternal health records. Obesity is defined as BMI of $\geq 27.5 \mathrm{~kg} / \mathrm{m}^{2}$ for Asian criteria-based BMI and $>30 \mathrm{~kg} / \mathrm{m}^{2}$ for International criteria-based BMI. Thirteen candidate genes were genotyped using Agena ${ }^{\circledR}$ MassARRAY and examined for association with pre-pregnancy obesity using multiple logistic regression analysis. The significant difference threshold was set at $\mathrm{P}$ value $<0.05$.

Results: Three hundred and twelve GDM women were included in this study; $60.9 \%$ and $44.2 \%$ of GDM patients were obese using Asian and International criteria-based BMI, respectively. GDM patients with AA or AG genotypes in specific SNP of brain-derived neurotrophic factor (BDNF) (G > A in rs6265) are more likely to be obese (adjusted odd ratio $=2.209,95 \% \mathrm{CI}, 1.305,3.739, \mathrm{P}=0.003$ ) compared to those who carry the GG genotype in the SNP adjusted for parity, underlying with asthma, heart disease, anaemia, education background in the International criteria-based BMI stratification group. On the other hand, there were no associations between other candidate genes (NRG1, FKBP5, RORA, OXTR, PLEKHG1, HTR2C, LHPP, SDK2, TEX51, EPHX2, NPY5R and ANO2) and maternal obesity.

Conclusions: In summary, $B D N F$ rs6265 is significantly associated with pre-pregnancy obesity among GDM patients. The exact role of $B D N F$ adjusted for diet intake and lifestyle factors merits further investigation.

Keywords: Polymorphisms; genetic variation; obesity; brain-derived neurotrophic factor (BDNF); gestational diabetes

\footnotetext{
^ ORCID: Siew Mooi Ching: 0000-0002-4425-7989; Kai Wei Lee: 0000-0001-9737-8066; Navin Kumar Devaraj: 0000-0001-8097-3192;
} Fan Kee Hoo: 0000-0003-1687-627X. 
Submitted Feb 16, 2020. Accepted for publication Jul 30, 2020.

doi: $10.21037 /$ atm-20-1579

View this article at: http://dx.doi.org/10.21037/atm-20-1579

\section{Introduction}

Pre-pregnancy obesity is a major burden throughout the world, especially in developing countries (1). Obesity in increasing worldwide, especially in Asia (2) and the prevalence of obesity among women is higher than in men (3). Pre-pregnancy obesity is a predictor of adverse pregnancy outcomes, with many studies reporting that prepregnancy obesity is associated with higher odds of having gestational diabetes mellitus $(\mathrm{GDM})$ [odd ratio $(\mathrm{OR})=3.98$ ]; gestational hypertension disorders $(\mathrm{OR}=3.68)$; preeclampsia ( $\mathrm{OR}=3.20)$, macrosomia ( $\mathrm{OR}=2.17)(4-6)$; preterm delivery [relative risk $(\mathrm{RR})=1.35$ ]; and caesarean section $(\mathrm{RR}=1.66)$ as compared to women with normal weight (6).

Studies have reported that pre-pregnancy obesity is associated with dietary preference, sedentary lifestyle and lack of awareness in metabolic management $(7,8)$, however the underlying mechanism for these associated factors can influence metabolism in women still remains unclear. Genetic factors are now regarded as a highly plausible explanation for explaining the association between prepregnancy obesity and aforementioned associated factors (9-11) as studies have shown that genetic factors had contributed e to $40 \%$ to $70 \%$ of variation in the risk of developing obesity (9-12).

Candidate gene studies are hypothesis-driven, and numerous of genes have been tested for obesity. Evidence from studies worldwide across different populations has been used to establish a human obesity gene map $(13,14)$. Nevertheless, interest remains in the analysis of candidate genes for the reason that certain candidate genes may have overlapping functions across various traits and diseases (15). To this end, we address this issue for obesity-susceptibility by constructing a custom of single nucleotide polymorphism (SNP) array containing thirteen candidate genes that were previously tested and found to have an association with either obesity or psychiatric symptoms.

This custom SNPs provides excellent coverage of many previously tested neuroendocrine disorder-related candidate genes for obesity, including brain-derived neurotrophic factor $(B D N F)(16,17)$, FKBP5 (18), NPYSR (19), EPHX2 (20) and TPH2 (21). In contrast, genetic association studies of obesity with the following neuroendocrine disorder-related candidate genes, such as ANO2 (22),
HTR2C (23), LHPP (24), NRG1 (25), OXTR (26), RORA (27), SDK2 (22), TEX51 (22) and PLEKHG1 (22) have not been evaluated. It is well known that obesity is closely related to psychiatry symptoms, since a large proportion of individuals with psychiatric symptoms such as depression or anxiety also tend to be obese (28-30); Similarly, those who are obese are at higher risk of developing depression or anxiety symptoms $(28,31,32)$. In addition, there is increasing support for the notion that obesity is a neuroendocrine disorder in which increased leptin, insulin, glucose, triglycerides, and inflammatory cytokines lead to alterations in hypothalamic pituitary adrenal axis, serotonergic and dopaminergic system, increasing the risk of behavioural and mental health disorders (33-35). Thus, the relevance of neuroendocrine disorders-related candidate genes in predisposal for prepregnancy obesity is worth investigating.

The aim of the present study was to perform neuroendocrine disorder-related candidate gene analysis via mass array to evaluate the association between prepregnancy obesity and thirteen candidate genes adjusted for socio-demographical background, maternal and clinical profile among GDM women using a stratification approach. The association analysis between the candidate genes and pre-pregnancy obesity was as defined by Asian and International criteria-based body mass index (BMI) groups and independently analysed. We present the following article in accordance with the STREGA reporting checklist (available at http://dx.doi.org/10.21037/atm-20-1579) (36).

\section{Methods}

\section{Study population}

We performed a post-hoc case-control analysis of a crosssectional study among GDM women $(\mathrm{n}=312)$ to check for candidate SNPs that may be associated with obesity in this particular population according to the Asian and International criteria-based BMI.

The study participants were women with GDM who were enrolled for a cross-sectional study (37). All participants were native Malaysian with GDM and residents of surrounding areas. They were recruited during second or third trimester care at two tertiary hospitals in Klang Valley, 
Malaysia between $1^{\text {st }}$ June 2018 and $31^{\text {st }}$ October 2018. The inclusion criteria were previously described in the study by Lee et al., 2019 (37). In brief, the participant must be a Malaysian woman, pregnant, 18 years of age or older and with a diagnosis of GDM according to Malaysian Clinical Practice Guidelines (38,39).

\section{Socio-demographic background and clinical characteristics}

Socio-demographic backgrounds and clinical characteristics were recorded at enrollment to obtain information related to maternal profile, past-obstetrics history, concurrent medical problems, family history and psychiatric symptoms (including depression, anxiety and stress). These data were obtained from the self-administered questionnaire and medical records.

\section{Measurement of pre-pregnancy obesity}

The anthropometric data of participants were obtained from each mother's health records. Pre-pregnancy weight and height were self-reported by the pregnant mothers and recorded by a medical assistant during the first antenatal booking. Pre-pregnancy obesity is defined as women with a $\mathrm{BMI} \geq 30 \mathrm{~kg} / \mathrm{m}^{2}$ before the pregnancy visit by using the international BMI classification (40). It is calculated by dividing weight at pre-pregnancy weight in kilograms $(\mathrm{kg})$ by height in meters squared $\left(\mathrm{m}^{2}\right)(41)$. BMI it is used to estimate the total body fat and assesses the risk for diseases related to increased body fat. The WHO criteria for International criteria-based BMI classifies a BMI of $<18.5 \mathrm{~kg} / \mathrm{m}^{2}$ as underweight; $18.5-24.9 \mathrm{~kg} / \mathrm{m}^{2}$ (as normal); $25.0-29.9 \mathrm{~kg} / \mathrm{m}^{2}$ (overweight); and $>30 \mathrm{~kg} / \mathrm{m}^{2}$ as obese (42-44).

Studies have showed that Asian people may have increased health risks at a lower BMI compared to Caucasians; therefore, the Asian criteria-based BMI was modified specifically for Asian adults. Its cut-off points are lower than those defined for International criteria. For instance, $\mathrm{WHO}$ recommended cut-points for Asian criteriabased BMI categories as follows: $<18.5 \mathrm{~kg} / \mathrm{m}^{2}$ (underweight); $18.5-22.9 \mathrm{~kg} / \mathrm{m}^{2}$ (normal); $23.0-27.4 \mathrm{~kg} / \mathrm{m}^{2}$ (overweight) and $\geq 27.5$ (obesity) $(45,46)$. This categorizing scheme follows National Institute for Health and Care Excellence (NICE) recommendations for Asians $(47,48)$.

\section{Participants}

Regarding patients and controls, we analyzed the association between candidate genes and obesity using two different criteria-based BMI categories which are the Asian and International criteria based BMI categories. Participants in control group were those patients with normal weight and those overweight as defined using BMI value, while participants in the patient group were those defined as being obese. Upon completion of sample collection and analysis, data for baseline BMI and polymorphisms of candidate genes were readily available for a total of 312 participants.

\section{Study outcomes, predictors and potential confounders}

The study outcomes were association between genetic polymorphism in neuroendocrine disorder-related candidate genes and pre-pregnancy obesity. The association was presented in crude OR and adjusted OR (95\% confidence interval). The predictors in this study were neuroendocrine disorder-related candidate genes. The potential confounders were socio-demographic background and clinical characteristics.

\section{Blood sample collection, DNA extraction and Mass-array genotyping}

Detailed blood sampling and DNA extraction methods have been previously described (49). In brief, $5 \mathrm{~mL}$ of blood samples of participants were collected by a phlebotomist and genomic DNA was isolated by using the QIAamp Blood DNA Mini Kit (QIAGEN, Hilden, Germany). The genotyping analysis for candidate genes polymorphism was conducted using the Agene ${ }^{\circledR}$ MassARRAY platform. SNP analysis performed using a Typer Analyzer.

\section{Bias}

We performed Bonferroni correction for multiple statistical significance tests to minimize bias arising from multiple testing errors.

\section{Sample size calculation}

The sample size was calculated using the following formula:

$$
\mathrm{n}=\mathrm{Z}_{\mathrm{a} / 2} \mathrm{p}^{\wedge}\left(1-\mathrm{p}^{\wedge}\right) / \mathrm{e}^{2}(50)
$$

Let $\mathrm{p}^{\wedge}=$ population proportion of class of interest, here $\mathrm{p}^{\wedge}=0.237(16) ; Z_{\mathrm{a} / 2}=$ population distribution for one sided test; and e = maximum error allow, say 0.07 (50).

$$
\mathrm{n}=\mathrm{Z}_{\mathrm{a} / 2} \mathrm{p}^{\wedge}\left(1-\mathrm{p}^{\wedge}\right) / \mathrm{e}^{2}
$$


If $\mathrm{Z}_{\mathrm{a} / 2}(0.95)=1.96 ; \mathrm{p}^{\wedge}=0.237$ and $\mathrm{e}=0.07$, then the sample size is:

$$
\begin{aligned}
& \mathrm{n}=(1.96)^{2}(0.237)(0.763) /(0.07)^{2} \\
& \mathrm{n}=3.8416(0.1808) / 0.005
\end{aligned}
$$

$\mathrm{n}=0.6946 / 0.005$

$\mathrm{n}=139$. Thus, around 139 obese GDM women to estimate $\mathrm{p}$ with $95 \%$ CI was needed.

\section{Quantitative variables}

Data on socio-demographic background, clinical characteristics and candidate genes are presented in term of $\mathrm{N}(\%)$. Dependent variables were categorized into two groups: normal or overweight group and obese group. Data on age and monthly family income are presented in mean \pm standard deviation.

\section{Statistical analysis}

We used IBM SPSS Statistics version 21.0 to perform the data analysis. A chi-square goodness-of-fit test was performed to assess the agreement of the genotype distribution among candidate genes using Hardy-Weinberg equilibrium, in which if the $\mathrm{P}$ value for chi-square goodness-of-fit tests is significant $(\mathrm{P}<0.05)$, the population is not in Hardy-Weinberg equilibrium. If the genotype distribution of candidate genes does not fit Hardy-Weinberg equilibrium based on equal distribution, the expected values for genotype distribution will be adjusted according to the global population. Univariate analysis was used to analyse the association between candidate genes and obesity among the GDM mothers. Significant difference is set at a $\mathrm{P}$ value $<0.05$. In addition, we tested the candidate gene polymorphism associations with obesity and any polymorphism adjusted for socio-demographical and clinical moderator effects. Variables with a P value of less than 0.25 in univariate analysis underwent Bonferroni correction for multiple statistical significance tests. Variables with $P$ value of less than 0.25 after a Bonferroni adjustment were entered into the multiple logistic regression analysis (51), adjusting for the fact that a rigidly set $\mathrm{P}$ value at $<0.05$ may miss many clinically important variables $(52,53)$. A backward stepwise regression method was used (54). All analyses were made with a $95 \%$ CI, and the level of significance was set at $\mathrm{P}<0.05$.

\section{Ethical consideration}

The study was conducted in accordance with the
Declaration of Helsinki (as revised in 2013). The study was approved by The Medical Research Ethics Committee, Ministry of Health Malaysia (No. NMRR-17-2264-37814) and informed consent was taken from all the patients.

\section{Results}

We found that $60.9 \%$ of GDM patients were obese using the Asian criteria-based BMI higher than the percentage of GDM patients with obesity (44.2\%) using the International criteria-based BMI. We found a significant association only in the association between specific SNP (rs6265) of gene $B D N F$ and pre-pregnancy obesity using International criteria-based BMI but not in Asian criteria-based BMI.

Analyses of the socio-demographic characteristics, past obstetric history, concurrent medical problems and family history of the 312 participants as stratified by Asian and International criteria-based BMI were performed and is shown in Table 1. Among the independent variables that were investigated, a significant difference was observed only in concurrent medical problems which were asthma and anaemia after a Bonferroni adjustment in the context of family-wise error for Asian criteriabased BMI categorization among GDM women $(\mathrm{P}<0.05)$. Asthma $(\mathrm{P}<0.05)$ was the only independent variable with a significant difference after a Bonferroni adjustment in the context of family-wise error for International criteria-based BMI categorization.

Analyses of the NRG1, FKBP5, RORA, OXTR, BDNF, $P L E K H G 1$ and HTR2C genotypes among the GDM patients with and without obesity $(\mathrm{n}=312)$ as stratified by Asian and International criteria-based BMI using the univariate analysis is shown in Table 2. Analyses of the LHPP, SDK2, TEX51, EPHX2, NPY5R and ANO2 genotype among GDM women with or without obesity that were stratified by Asian and International criteria-based BMI are shown in Table S1, because these candidate genes have a $\mathrm{P}$ value $>0.25$ using univariate analysis.

Notably, the proportion of the AG or AA genotypes was higher than that of the GG genotype in SNP of BDNF (G $>\mathrm{A}$ in rs6265) among obese GDM women (57.7\% versus $42.3 \% ; \mathrm{P}=0.024$ after a Bonferroni adjustment) as shown in Table 2. On the other hand, there were no significant associations between SNPs for candidate genes (NRG1, FKBP5, RORA, OXTR, PLEKHG1 and HTR2C) and prepregnancy obesity $(\mathrm{P}>0.05)$ in both stratification groups.

The associations between specific SNP's genotype of candidate genes and pre-pregnancy obesity adjusted for 
Table 1 Univariate analysis on the socio-demographic background and clinical characteristics of the participants with and without obesity (n=312)

\begin{tabular}{|c|c|c|c|c|c|c|c|}
\hline \multirow[b]{2}{*}{ Parameters } & \multirow[b]{2}{*}{ Category } & \multicolumn{3}{|c|}{ Asian criteria-based BMI } & \multicolumn{3}{|c|}{ International criteria-based BMI } \\
\hline & & $\begin{array}{c}\text { Normal and } \\
\text { overweight }(n=122)\end{array}$ & Obese $(n=190)$ & $P$ value & $\begin{array}{c}\text { Normal and } \\
\text { overweight }(n=174)\end{array}$ & Obese $(n=138)$ & $P$ value \\
\hline Age & & $31.98 \pm 5.17$ & $32.16 \pm 4.87$ & 0.757 & $32.05 \pm 4.98$ & $32.15 \pm 5.00$ & 0.852 \\
\hline Ethnicity & Malay & $98(38.6)$ & $156(61.4)$ & 0.694 & $138(54.4)$ & $116(45.7)$ & 0.284 \\
\hline \multirow[t]{2}{*}{ Religion } & Muslim & $101(39.1)$ & $157(60.9)$ & 0.972 & $142(55.0)$ & $116(45.0)$ & 0.570 \\
\hline & Non-Muslim & $21(38.9)$ & $33(61.1)$ & & $32(59.3)$ & $22(40.7)$ & \\
\hline Education & $\begin{array}{l}\text { Secondary and } \\
\text { below }\end{array}$ & $61(37.0)$ & $104(63.0)$ & 0.419 & $83(50.3)$ & $82(49.7)$ & $0.039^{\mathrm{a}}$ \\
\hline $\begin{array}{l}\text { Monthly family } \\
\text { income, Ringgit } \\
\text { Malaysia }\end{array}$ & & $3,720.89 \pm 2,263.29$ & $3,479.65 \pm 2,338.73$ & 0.282 & $3,823.04 \pm 2,204.97$ & $3,263.49 \pm 2,404.31$ & 0.042 \\
\hline \multirow[t]{2}{*}{ Marital status } & Without husband & $4(30.8)$ & $9(69.2)$ & 0.529 & $6(46.2)$ & $7(53.8)$ & 0.476 \\
\hline & With husband & $118(39.5)$ & $181(60.5)$ & & $168(56.2)$ & $131(43.8)$ & \\
\hline \multirow[t]{2}{*}{ Parity } & $\begin{array}{l}\text { Nulliparous- } \\
\text { Primiparous }\end{array}$ & $58(34.7)$ & $109(65.3)$ & $0.089^{a}$ & $85(50.9)$ & $82(49.1)$ & $0.063^{a}$ \\
\hline & Multiparous $\geq 2$ & $64(44.1)$ & $81(55.9)$ & & $89(61.4)$ & $56(38.6)$ & \\
\hline Smoking habit & No & $121(39.5)$ & $185(60.5)$ & 0.41 & $173(56.5)$ & $133(43.5)$ & $0.091^{b}$ \\
\hline Abortion & Yes & $30(36.1)$ & $53(63.9)$ & & $44(53.0)$ & $39(47.0)$ & \\
\hline \multirow[t]{2}{*}{ Macrosomia } & No & $119(39.0)$ & $186(61.0)$ & 1.000 & $171(56.1)$ & $134(43.9)$ & 0.704 \\
\hline & Yes & 3 (42.9) & $4(57.1)$ & & $3(42.9)$ & $4(57.1)$ & \\
\hline \multirow{2}{*}{$\begin{array}{l}\text { Gestational } \\
\text { hypertension }\end{array}$} & No & $117(39.4)$ & $180(60.6)$ & 0.639 & 166 (55.9) & $131(44.1)$ & 0.846 \\
\hline & Yes & 5 (33.3) & $10(66.7)$ & & $8(53.3)$ & $7(46.7)$ & \\
\hline \multirow[t]{2}{*}{ Stillbirth } & No & $117(39.0)$ & $183(61.0)$ & 1.000 & 166 (55.3) & $134(44.7)$ & 0.438 \\
\hline & Yes & $5(41.7)$ & 7 (58.3) & & $8(66.7)$ & $4(33.3)$ & \\
\hline \multirow[t]{2}{*}{ Preterm delivery } & No & $115(38.5)$ & $184(61.5)$ & 0.266 & $166(55.5)$ & $133(44.5)$ & 0.669 \\
\hline & Yes & $7(53.8)$ & $6(46.2)$ & & $8(61.5)$ & $5(38.5)$ & \\
\hline \multirow{2}{*}{$\begin{array}{l}\text { Gestational diabetes } \\
\text { mellitus }\end{array}$} & No & $96(40.2)$ & $143(59.8)$ & 0.486 & $135(56.5)$ & $104(43.5)$ & 0.645 \\
\hline & Yes & 26 (35.6) & $47(64.4)$ & & $39(53.4)$ & $34(46.6)$ & \\
\hline
\end{tabular}

Table 1 (continued) 
Table 1 (continued)

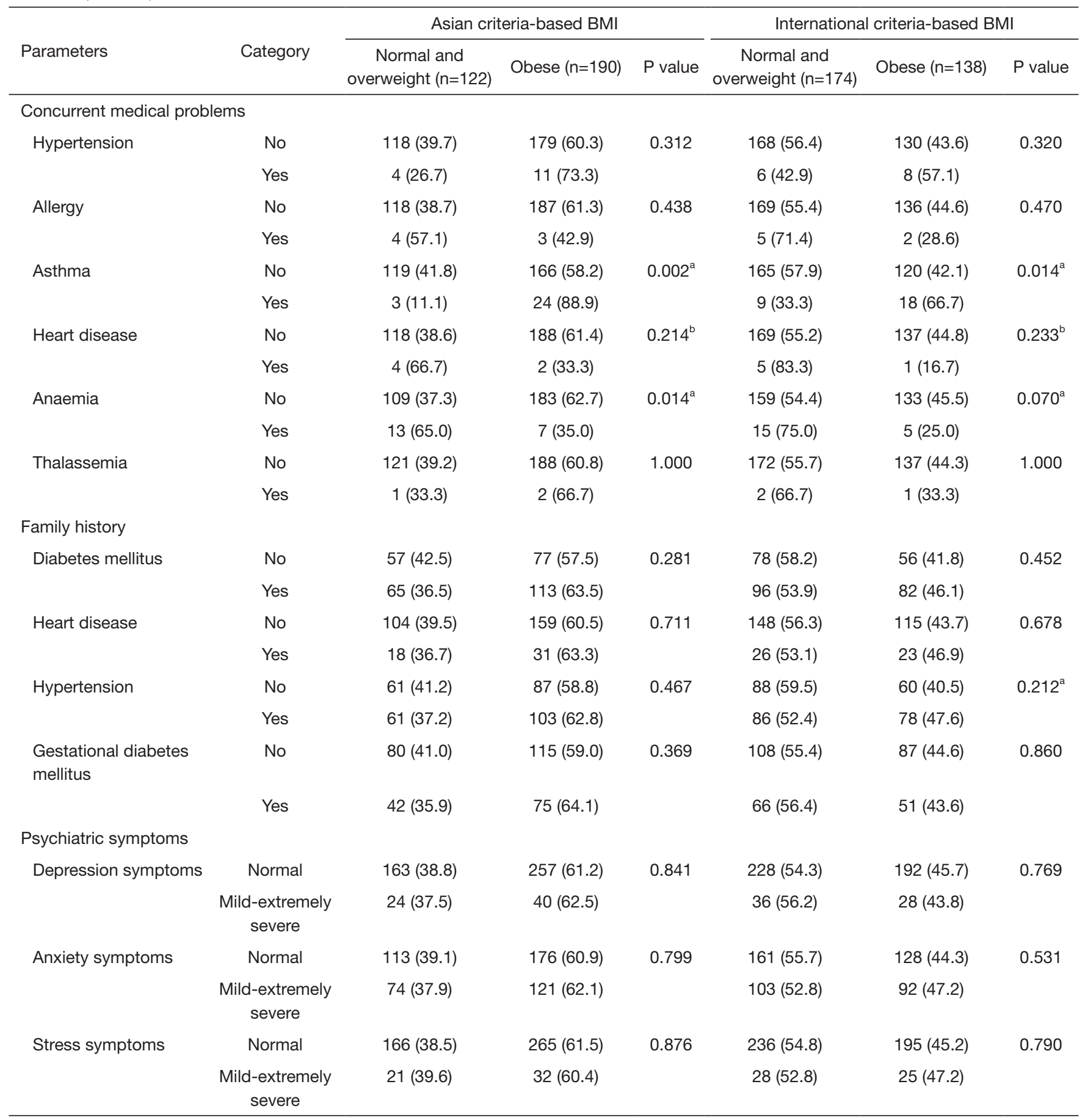

Data are presented as either $\mathrm{n}(\%)$ or mean $\pm \mathrm{SD}$. ${ }^{\mathrm{a}}$, Pearson Chi-square at $\mathrm{P}<0.25$ entered Bonferroni adjustment before multiple regression analysis. ${ }^{b}$, Fisher's Exact test at $\mathrm{P}<0.25$ entered Bonferroni adjustment before multiple regression analysis. After a Bonferroni adjustment in the context of family-wise error for Asian criteria-based BMI categorization among GDM women, the adjusted $\mathrm{P}$ value for parity was 0.152 , asthma $(P=0.001)$, heart disease $(P=0.226)$, and anaemia $(P=0.031)$. After a Bonferroni adjustment in the context of family-wise error for International criteria-based BMI categorization among GDM women, the adjusted $\mathrm{P}$ value for education was 0.075 , parity $(P=0.109)$, smoking habit $(P=0.109)$, asthma $(P=0.031)$, heart disease $(P=0.226)$, anaemia $(P=0.129)$ and family history of hypertension ( $P=0.276)$. BMI, body mass index; GDM, gestational diabetes mellitus. 
Table 2 Analyses of the NRG1, FKBP5, RORA, OXTR, BDNF, PLEKHG1 and HTR2C genotypes among the GDM patients with and without obesity $(\mathrm{n}=312)$

\begin{tabular}{|c|c|c|c|c|c|c|c|c|}
\hline $\begin{array}{l}\text { Candidate } \\
\text { genes }\end{array}$ & SNP & Genotype & \multicolumn{3}{|c|}{ Asian criteria-based BMI } & \multicolumn{3}{|c|}{ International criteria-based BMI } \\
\hline \multirow{4}{*}{$N R G 1$} & & $\mathrm{TC}$ & $60(49.2)$ & $84(44.4)$ & & $88(50.6)$ & $56(40.9)$ & \\
\hline & & C carrier & $80(65.6)$ & $104(55.0)$ & & $112(64.4)$ & $72(52.6)$ & \\
\hline & & T carrier & $102(83.6)$ & $169(89.4)$ & $0.135^{\mathrm{a}}$ & $150(86.2)$ & $121(88.3)$ & 0.580 \\
\hline & & CC genotype & $20(16.4)$ & $20(10.6)$ & & $24(13.8)$ & $16(11.7)$ & \\
\hline \multirow{4}{*}{ FKBP5 } & & TT genotype & $56(47.9)$ & $78(41.1)$ & $0.243^{\mathrm{a}}$ & $80(47.3)$ & $54(39.1)$ & $0.149^{a}$ \\
\hline & & G carrier & $61(52.1)$ & $112(58.9)$ & & $89(52.7)$ & $84(60.9)$ & \\
\hline & & T carrier & $108(92.3)$ & 169 (88.9) & 0.336 & $152(89.9)$ & $125(90.6)$ & 0.851 \\
\hline & & GG genotype & $9(7.7)$ & $21(11.1)$ & & $17(10.1)$ & $13(9.4)$ & \\
\hline \multirow[t]{3}{*}{$R O R A$} & rs4775340 & GG & $79(64.8)$ & $11862.4)$ & 0.878 & $112(64.4)$ & $85(62.0)$ & 0.288 \\
\hline & & GA & 38 (31.1) & 64 (33.9) & & $53(30.5)$ & 49 (35.8) & \\
\hline & & AA & $5(4.1)$ & $7(3.7)$ & & $9(5.2)$ & $6(2.2)$ & \\
\hline \multirow{6}{*}{ OXTR } & & $A G$ & 65 (53.7) & $92(48.4)$ & & $90(52.0)$ & $67(48.6)$ & \\
\hline & & GG & 23 (19.0) & $51(26.8)$ & & 37 (21.4) & 37 (26.8) & \\
\hline & & AA genotype & $33(27.3)$ & 47 (24.7) & 0.618 & $46(26.6)$ & 34 (24.6) & 0.696 \\
\hline & & G carrier & $88(72.7)$ & $143(75.3)$ & & $127(73.4)$ & $104(75.4)$ & \\
\hline & & A carrier & $98(81.0)$ & $139(73.2)$ & $0.114^{\mathrm{a}}$ & 1136 (78.6) & $101(73.2)$ & 0.264 \\
\hline & & GG genotype & $23(19.0)$ & $51(26.8)$ & & 37 (21.4) & $37(26.8)$ & \\
\hline
\end{tabular}

Table 2 (continued) 
Table 2 (continued)

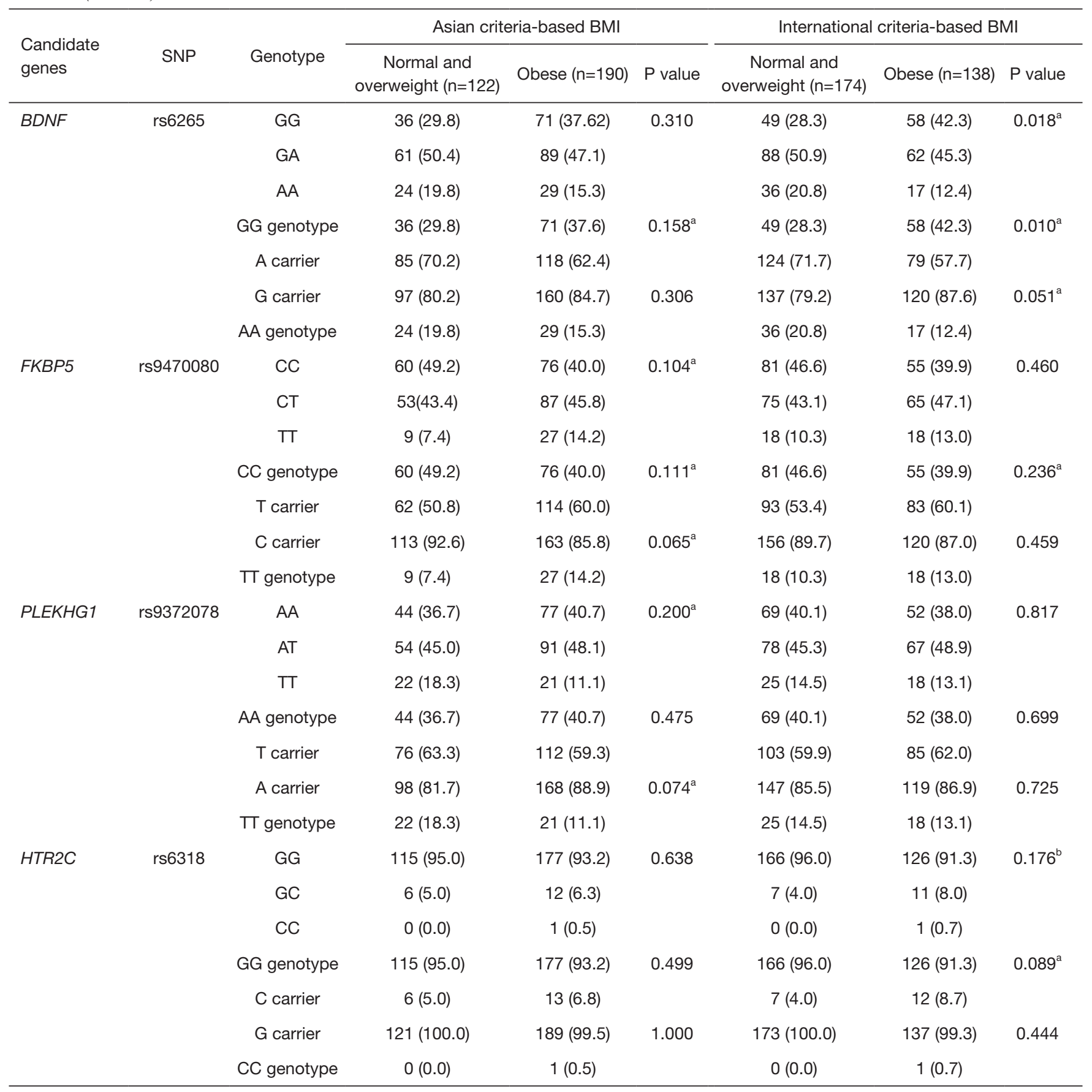

Data are presented as either $\mathrm{n}(\%) .{ }^{\text {a }}$, Pearson Chi-square at $\mathrm{P}<0.25$ entered Bonferroni adjustment before multiple regression analysis.

b, Fisher's Exact test at $\mathrm{P}<0.25$ entered Bonferroni adjustment before multiple regression analysis. After a Bonferroni adjustment in the context of family-wise error for Asian criteria-based BMl categorization among GDM women, the adjusted P value for NRG1 (rs2919375) was 0.129, FKBP5 (rs3800373) was 0.276, OXTR (rs53576) was 0.175, BDNF (rs6265) was 0.226, FKBP5 (rs9470080) was 0.129 and PLEKHG1(rs9372078) was 0.129. After a Bonferroni adjustment in the context of family-wise error for International criteria-based BMI categorization among GDM women, the adjusted P value for NRG1 (rs2919375) was 0.075, FKBP5 (rs3800373) was 0.226, RORA (rs4775340) was 0.226, BDNF (rs6265) was 0.024, FKBP5 (rs9470080) was 0.276, and HTR2C (rs6318) was 0.152. BMI, body mass index; SNP, single nucleotide polymorphisms; GDM, gestational diabetes mellitus. 
Table 3 Multiple regression analysis between genotypes of candidate genes for obesity among the GDM patients stratified using Asian criteriabased BMI classifications adjusted for confounding factors $(\mathrm{n}=312)$

\begin{tabular}{|c|c|c|c|}
\hline $\begin{array}{l}\text { Candidate genes (SNP) or } \\
\text { factors }\end{array}$ & Genotypes & \multicolumn{2}{|c|}{ Asian criteria-based BMI } \\
\hline \multirow[t]{2}{*}{ NRG1 (rs2919375) } & $\pi$ & 1 & 1 \\
\hline & $\mathrm{TC} / \mathrm{CC}$ & 1.545 (0.932, 2.560), 0.091 & $1.604(0.972,2.647), 0.065$ \\
\hline OXTR (rs53576) & AA/AG & $1.753(0.959,3.205), 0.068$ & 1.785 (0.977, 3.262), 0.060 \\
\hline \multirow[t]{2}{*}{$B D N F($ rs6265) } & GG & 1 & 1 \\
\hline & AA/AG & $1.259(0.743,2.132), 0.392$ & $1.259(0.743,2.132), 0.392$ \\
\hline \multirow[t]{2}{*}{ FKBP5 (rs9470080) } & $\mathrm{CC} / \mathrm{CT}$ & 2.166 (0.891, 5.263), 0.088 & $2.263(0.950,5.392), 0.065$ \\
\hline & $\pi$ & 1 & 1 \\
\hline \multirow[t]{2}{*}{ Parity } & Nulliparous-Primiparous & $1.542(0.937,2.540), 0.089$ & $1.598(0.976,2.617), 0.062$ \\
\hline & Multiparous $\geq 2$ & 1 & 1 \\
\hline \multirow[t]{2}{*}{ Asthma } & No & 1 & 1 \\
\hline & Yes & $6.655(1.770,25.020), 0.005$ & $5.738(1.598,20.602), 0.007$ \\
\hline \multirow[t]{2}{*}{ Heart disease } & No & $4.105(0.427,39.442), 0.221$ & $4.415(0.460,42.357), 0.198$ \\
\hline & Yes & 1 & 1 \\
\hline \multirow[t]{2}{*}{ Anaemia } & No & $4.944(1.685,14.506), 0.004$ & 5.239 (1.810, 15.171), 0.002 \\
\hline & Yes & 1 & 1 \\
\hline
\end{tabular}

Adjusted OR was determined by adjusting for socio-demographical and clinical moderators with $\mathrm{P}$ value $<0.25$ in univariate analysis. BMI, body mass index; GDM, gestational diabetes mellitus.

socio-demographic characteristics and concurrent medical problems are shown in Table 3 for Asian criteria-based BMI classification, and Table 4 for International criteriabased BMI classification. GDM patients with the AA or AG genotypes in specific SNP of $B D N F(\mathrm{G}>\mathrm{A}$ in rs6265) have a 2.2 times higher odds to be obese compared to those who carry GG genotype in the SNP adjusted for parity, underlying with asthma, heart disease, anaemia, education background, smoking habit and monthly family income in the International criteria-based BMI stratification group. GDM patients with underlying asthma appeared to be significantly associated with pre-pregnancy obesity in both stratification groups, with GDM patients with underlying asthma having a 5.7 times and 2.7 times higher odds to be obese compared to those without underlying asthma in Asian and International criteria-based BMI, respectively.

We performed additional analysis to determine the association, if any between candidate gene $B D N F(\mathrm{G}>\mathrm{A}$ in rs6265) and psychiatric symptoms (depression, anxiety and stress symptoms). The results are presented in Table 5. The analysis showed that there was no statistically significant association between $B D N F(\mathrm{G}>\mathrm{A}$ in rs6265) and psychiatric symptoms among Malaysian women with GDM.

\section{Discussion}

Over the years, an increasing number of polymorphisms in candidate genes related to obesity have been discovered. In this study, we performed univariate logistic regression for every candidate gene, followed by multiple logistic regressions to elucidate the association between candidate genes and pre-pregnancy obesity among GDM patients. To our knowledge, this is the first study to examine the candidate genes for pre-pregnancy obesity among 
Table 4 Multiple regression analysis between genotypes of candidate genes for obesity among the GDM patients stratified using International criteria-based BMI classifications adjusted for confounding factors $(\mathrm{n}=312)$

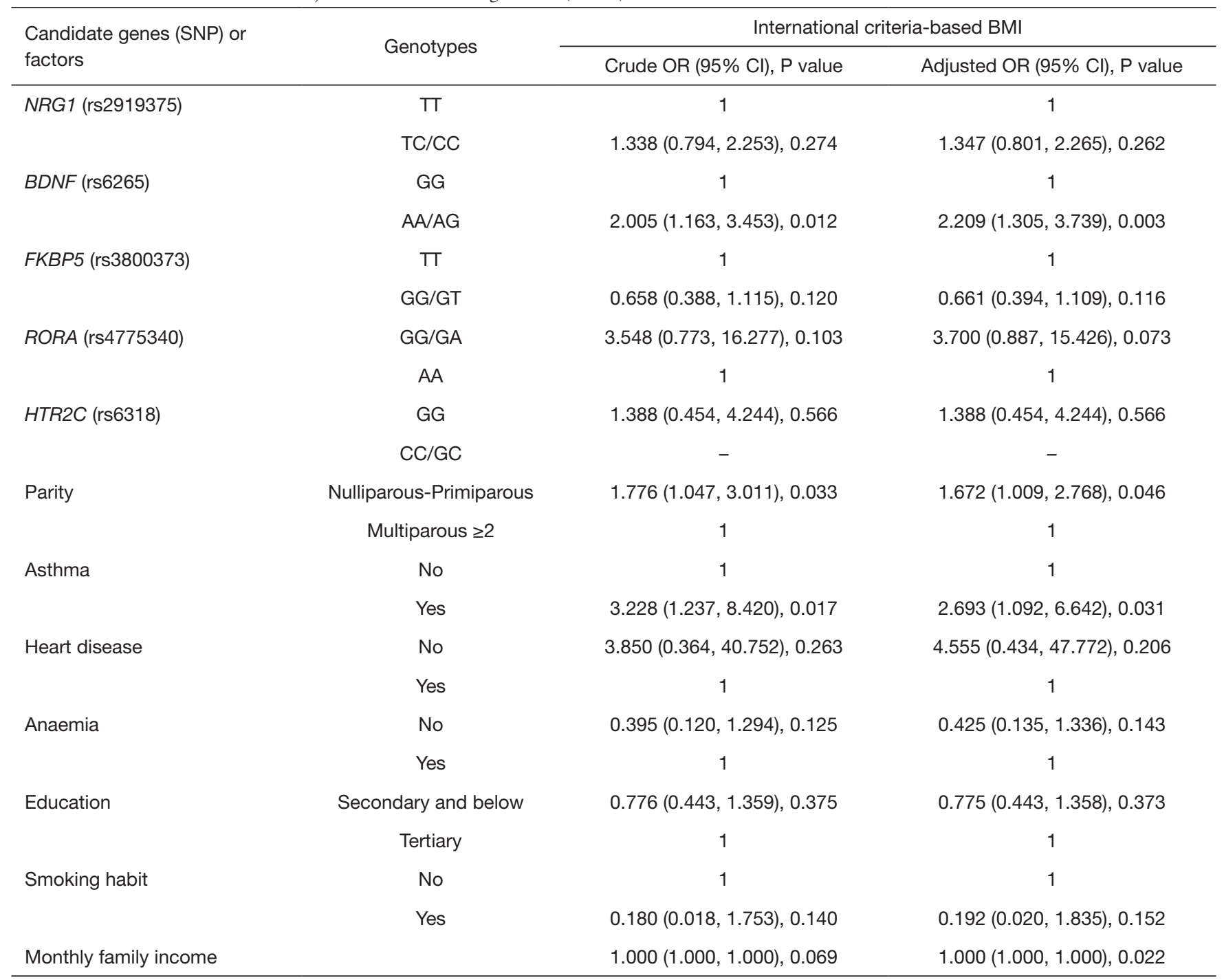

Adjusted OR was determined by adjusting for socio-demographical and clinical moderators with $\mathrm{P}$ value $<0.25$ in univariate analysis. BMI, body mass index; GDM, gestational diabetes mellitus.

Table 5 Univariate analysis of the $B N D F$ rs6265 for psychiatric symptoms among women with gestational diabetes using International criteria based BMI classifications

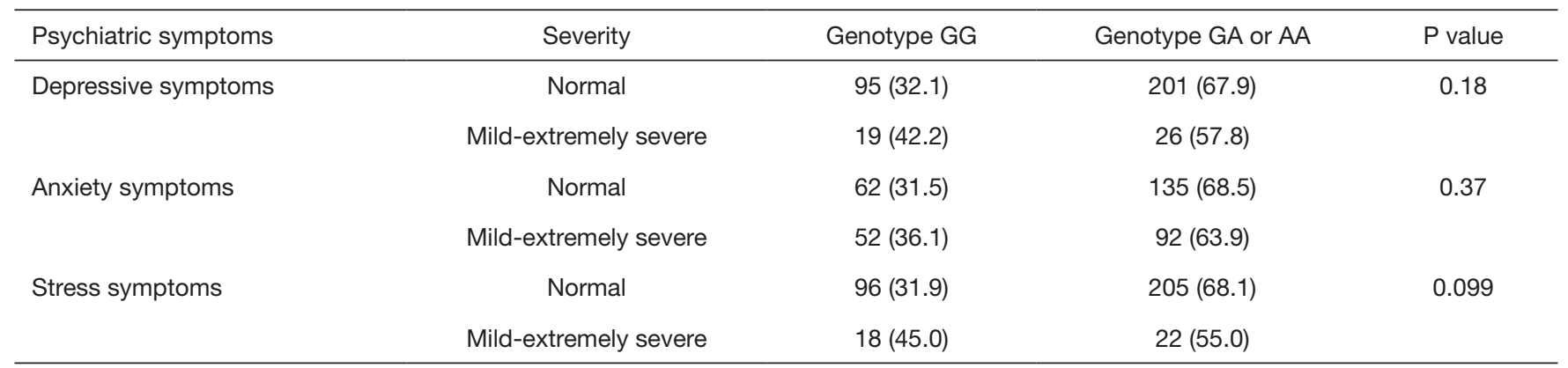

BDNF, brain-derived neurotrophic factor; BMI, body mass index. 
GDM women in Malaysia. It is also the first study to use stratification approach by both Asian and International criteria-based $\mathrm{BMI}$ in performing the association analysis for candidate genes.

It is worth mentioning that $60.9 \%$ of GDM patients in this study were obese using the Asian-criteria-based BMI, while only around two-fifth were obese using International criteria-based BMI. Even though the percentage of obesity among GDM patient using International criteria-based BMI appeared to be lower than that when using Asiancriteria-based BMI, it is noteworthy that types of criteriabased BMI used often has an influence on the association analysis between candidate genes and obesity. For instance, we found out that there were only five candidate genes with a $\mathrm{P}$ value $<0.25$ in univariate analysis that were entered multiple regressions analysis, which included candidate genes of NRG1, OXTR, BNDF, FKBP5 and PLEKHG1 using the Asian criteria-based BMI. The five candidate genes with $\mathrm{P}$ value $<0.25$ in univariate analysis entered into the multiple regressions analysis using the International criteria-based BMI were NRG1, FKBP5, RORA, BNDF and HTR2C.

In this study, $B D N F$ was found to have an association with pre-pregnancy obesity using the International criteriabased BMI. A possible explanation is that $B D N F$ is a type of neurotrophic protein that contributes to suppressed food intake through hippocampal signalling $(55,56)$. Polymorphism in $B N D F$ gene could possibly decrease $B N D F$ expression and thus assist in promoting food intake and exhibit hyperphagic behaviour which may subsequently contributes to significant weight gain (57).

The association between $B D N F$ rs6265 genotypes and obesity is inconsistent among populations, as shown also in this study, where the carrier of A allele is associated with obesity in GDM patients. This finding is consistent with studies done on German (58), Belgian (16) and Estonian populations (59). However, our findings contradict the findings of studies done on American (60) and British populations (61). These studies discovered that those who carry G allele exhibited higher BMI than carriers of the A allele. These inconsistent findings may be due to differences in dietary intake and lifestyle factors, which could modify the association between genotype and obesity traits.

\section{Study strength and limitations}

This study has generated exciting findings for an association between genetic variant in SNP of BDNF gene and maternal obesity, which further establishes the role of SNP of $B D N F$ (rs6265) in obesity in women adjusted for socio-demographic characteristics and concurrent medical problems.

Limitations may also be present in our study. The association between candidate genes and pre-pregnancy obesity traits could be modulated by the gene-diet-lifestyle interactions; however information on diet intake, lifestyle factors and physical activity was not captured in this study. Therefore the association between candidate genes and pre-pregnancy obesity as shown in this study should be interpreted cautiously.

\section{Conclusions}

In summary, our study found a significant association between $B N D F$ rs6265 variant and pre-pregnancy obesity among GDM patients. The $B D N F$ genotype appears to interact with concurrent medical problems in the Malaysian population, especially among GDM patients. The results indicate a role for $B D N F$ in obesity. Larger studies considering dietary intake and lifestyle factors are required to determine whether there is a true association between $B D N F$ gene and obesity.

\section{Acknowledgments}

Funding: This work was supported by the Universiti Putra Malaysia under Putra Graduate Initiative (UPM/700-2/1/ GP-IPS/2018/9593800), High Impact Grant (UPM/8003/3/1/GPB/2018/9659600) and Graduate Research Fellowship (UPM/SPS/GS48750). The funder had no role in study design, data collection and analysis, decision to publish or preparation of the manuscript.

\section{Footnote}

Reporting Checklist: The authors have completed the STREGA reporting checklist. Available at http://dx.doi. org/10.21037/atm-20-1579

Data Sharing Statement: Available at http://dx.doi. org/10.21037/atm-20-1579

Peer Review File: Available at http://dx.doi.org/10.21037/ atm-20-1579

Conflicts of Interest: All authors have completed the ICMJE 
uniform disclosure form (available at http://dx.doi. org/10.21037/atm-20-1579). The authors have no conflicts of interest to declare.

Ethical Statement: The authors are accountable for all aspects of the work in ensuring that questions related to the accuracy or integrity of any part of the work are appropriately investigated and resolved. The study was conducted in accordance with the Declaration of Helsinki (as revised in 2013). The study was approved by The Medical Research Ethics Committee, Ministry of Health Malaysia (No. NMRR-17-2264-37814) and informed consent was taken from all the patients.

Open Access Statement: This is an Open Access article distributed in accordance with the Creative Commons Attribution-NonCommercial-NoDerivs 4.0 International License (CC BY-NC-ND 4.0), which permits the noncommercial replication and distribution of the article with the strict proviso that no changes or edits are made and the original work is properly cited (including links to both the formal publication through the relevant DOI and the license). See: https://creativecommons.org/licenses/by-nc-nd/4.0/.

\section{References}

1. Hanprasertpong T. Overweight and Obesity in Pregnancy. Thai J Obstet Gynaecol 2020;28:2-5.

2. NCD Risk Factor Collaboration (NCD-RisC)_Americas Working Group. Trends in cardiometabolic risk factors in the Americas between 1980 and 2014: a pooled analysis of population-based surveys. Lancet Glob Health 2020;8:e123-e133.

3. Chooi YC, Ding C, Magkos F. The epidemiology of obesity. Metabolism 2019;92:6-10.

4. Najafi F, Hasani J, Izadi N, et al. The effect of prepregnancy body mass index on the risk of gestational diabetes mellitus: A systematic review and dose-response meta-analysis. Obes Rev 2019;20:472-86.

5. Santos S, Voerman E, Amiano P, et al. Impact of maternal body mass index and gestational weight gain on pregnancy complications: an individual participant data meta-analysis of European, North American and Australian cohorts. BJOG 2019;126:984-95.

6. Gaudet L, Ferraro ZM, Wen SW, et al. Maternal obesity and occurrence of fetal macrosomia: a systematic review and meta-analysis. Biomed Res Int 2014;2014:640291.

7. McIntyre HD, Dekker M, Barrett HL, et al. Obesity in
Pregnancy: Epidemiology, Mechanisms, Nutritional and Metabolic Management. Gestational Diabetes. Karger Publishers; 2020:21-34.

8. Poston L, Caleyachetty R, Cnattingius S, et al. Preconceptional and maternal obesity: epidemiology and health consequences. Lancet Diabetes Endocrinol 2016;4:1025-36.

9. Tyrrell J, Richmond RC, Palmer TM, et al. Genetic evidence for causal relationships between maternal obesityrelated traits and birth weight. Jama 2016;315:1129-40.

10. Yang X, Deignan JL, Qi H, et al. Validation of candidate causal genes for obesity that affect shared metabolic pathways and networks. Nat Genet 2009;41:415.

11. Speakman JR. Thrifty genes for obesity, an attractive but flawed idea, and an alternative perspective: the 'drifty gene' hypothesis. Int J Obes (Lond) 2008;32:1611.

12. Maes HH, Neale MC, Eaves LJ. Genetic and environmental factors in relative body weight and human adiposity. Behav Genet 1997;27:325-51.

13. Rankinen T, Zuberi A, Chagnon YC, et al. The human obesity gene map: the 2005 update. Obesity (Silver Spring) 2006;14:529-644.

14. Pinto RM. The Role of Genetics in the Pathophysiology of Obesity: A Systematic Review. Obes Res Open J 2019;6:11-7.

15. Vimaleswaran KS, Tachmazidou I, Zhao JH, et al. Candidate genes for obesity-susceptibility show enriched association within a large genome-wide association study for BMI. Hum Mol Genet 2012;21:4537-42.

16. Beckers S, Peeters A, Zegers D, et al. Association of the BDNF Val66Met variation with obesity in women. Mol Genet Metab 2008;95:110-2.

17. Schwartz E, Mobbs CV. Hypothalamic BDNF and obesity: found in translation. Nat Med 2012;18:496.

18. Fichna M, Krzyśko-Pieczka I, Żurawek M, et al. FKBP5 polymorphism is associated with insulin resistance in children and adolescents with obesity. Obes Res Clin Pract 2018;12:62-70.

19. Jenkinson CP, Cray K, Walder K, et al. Novel polymorphisms in the neuropeptide-Y Y5 receptor associated with obesity in Pima Indians. Int J Obes Relat Metab Disord 2000;24:580-4.

20. Ramirez CE, Shuey MM, Milne GL, et al. Arg287Gln variant of EPHX2 and epoxyeicosatrienoic acids are associated with insulin sensitivity in humans. Prostaglandins Other Lipid Mediat 2014;113-115:38-44.

21. Mazurina N, Galieva M, Troshina E, et al. editors. Polymorphisms of genes GNB3, SERT, NET, TPH2 
and results of obesity treatment with sibutramine. 21st European Congress of Endocrinology; 2019: BioScientifica. 10.1530/endoabs.63.P553.

22. Otowa T, Yoshida E, Sugaya N, et al. Genome-wide association study of panic disorder in the Japanese population. J Hum Genet 2009;54:122-6.

23. Yasseen B, Kennedy JL, Zawertailo LA, et al. Comorbidity between bipolar disorder and alcohol use disorder: Association of dopamine and serotonin gene polymorphisms. Psychiatry Res 2010;176:30-3.

24. Cui L, Wang F, Yin Z, et al. Effects of the LHPP gene polymorphism on the functional and structural changes of gray matter in major depressive disorder. Quant Imaging Med Surg 2020;10:257.

25. Wen Z, Chen J, Khan RAW, et al. Genetic association between NRG1 and schizophrenia, major depressive disorder, bipolar disorder in Han Chinese population. Am J Med Genet B Neuropsychiatr Genet 2016;171B:468-78.

26. Saravani R, Esmaeeli E, Tamendani MK, et al. Oxytocin receptor gene polymorphisms in patients with diabetes. Gene Cell Tissue 2015;2:e60171.

27. Ming Q, Wang X, Chai Q, et al. Retinoid-related orphan receptor alpha (RORA) gene variation is associated with trait depression. Psychiatry Res 2015;229:629.

28. Paulitsch RG, Demenech LM, Dumith SC. Association of depression and obesity is mediated by weight perception. J Health Psychol 2020. doi: 10.1177/1359105319897778.

29. Ning F, Zhang D, Xue B, et al. Synergistic effects of depression and obesity on type 2 diabetes incidence in Chinese adults. J Diabetes 2020;12:142-50.

30. Sharafi SE, Garmaroudi G, Ghafouri M, et al. Prevalence of anxiety and depression in patients with overweight and obesity. Obes Med 2020;17:100169.

31. Gibson-Smith D, Halldorsson TI, Bot M, et al. Childhood overweight and obesity and the risk of depression across the lifespan. BMC Pediatr 2020;20:25.

32. Adkins LD, Tucker A, Gatta LA, et al. Gestational Weight Gain and Postpartum Depression in Women with Class III Obesity. Am J Perinatol 2020;37:19-24.

33. Sullivan EL, Riper KM, Lockard R, et al. Maternal highfat diet programming of the neuroendocrine system and behavior. Horm Behav 2015;76:153-61.

34. Molyneaux E, Pasupathy D, Kenny L, et al. Socioeconomic status influences the relationship between obesity and antenatal depression: data from a prospective cohort study. J Affect Disord 2016;202:124-7.

35. Simon GE, Von Korff M, Saunders K, et al. Association between obesity and psychiatric disorders in the US adult population. Arch Gen Psychiatry 2006;63:824-30.

36. Little J, Higgins JP, Ioannidis JP, et al. STrengthening the REporting of Genetic Association Studies (STREGA) an extension of the STROBE statement. Genet Epidemiol 2009;33:581-98.

37. Lee KW, Ching SM, Hoo FK, et al. Prevalence and factors associated with depressive, anxiety and stress symptoms among women with gestational diabetes mellitus in tertiary care centres in Malaysia: a cross-sectional study. BMC Pregnancy Childbirth 2019;19:367.

38. Ministry of Health Malaysia. Clinical Practice Guidelines. Management of Diabetes in Pregnancy; 2017.

39. Malaysian Endocrine and Metabolic Society, Ministry of Health Malaysia. Management of Type 2 Diabetes Mellitus (5th Edition). Kuala Lumpur MEMS \& MOH; 2015.

40. Lausman A, Kingdom J, Gagnon R, et al. Intrauterine growth restriction: screening, diagnosis, and management. J Obstet Gynaecol Can 2013;35:741-8.

41. Organization WH. Obesity: preventing and managing the global epidemic. vol 894. World Health Organization; 2000.

42. Sahu MT, Agarwal A, Das V, et al. Impact of maternal body mass index on obstetric outcome. J Obstet Gynaecol Res 2007;33:655-9.

43. Sebire NJ, Jolly M, Harris J, et al. Is maternal underweight really a risk factor for adverse pregnancy outcome? A population-based study in London. BJOG 2001;108:61-6.

44. Nohr EA, Vaeth M, Baker JL, et al. Combined associations of prepregnancy body mass index and gestational weight gain with the outcome of pregnancy. Am J Clin Nutr 2008;87:1750-9.

45. WHO Expert Consultation. Appropriate body-mass index for Asian populations and its implications for policy and intervention strategies. Lancet 2004;363:157-63.

46. Liabsuetrakul T. Is international or Asian criteria-based body mass index associated with maternal anaemia, low birthweight, and preterm Births among Thai population? An observational study. J Health Popul Nutr 2011;29:218-28.

47. NIH conference. Gastrointestinal surgery for severe obesity. Consensus Development Conference Panel. Ann Intern Med 1991;115:956-61.

48. Stegenga H, Haines A, Jones K, et al. Identification, assessment, and management of overweight and obesity: summary of updated NICE guidance. BMJ 2014;349:g6608.

49. Lee KW, Ching SM, Ramachandran V, et al. Association Analysis of 14 Candidate Gene Polymorphism with 
Depression and Stress among Gestational Diabetes Mellitus. Genes 2019;10:988.

50. Caldwell S. Statistics unplugged. Wadsworth: Cengage Learning; 2012.

51. Bursac Z, Gauss CH, Williams DK, et al. Purposeful selection of variables in logistic regression. Source Code Biol Med 2008;3:17.

52. Bendel RB, Afifi AA. Comparison of stopping rules in forward "stepwise" regression. J Am Stat Assoc 1977;72:46-53.

53. Mickey RM, Greenland S. The impact of confounder selection criteria on effect estimation. Am J Epidemiol 1989;129:125-37.

54. Lomax RG. An introduction to statistical concepts for education and behavioral sciences. Psychology Press; 2001.

55. Monteleone P, Tortorella A, Martiadis V, et al. Opposite changes in the serum brain-derived neurotrophic factor in anorexia nervosa and obesity. Psychosom Med 2004;66:744-8.

56. El-Gharbawy AH, Adler-Wailes DC, Mirch MC, et al. Serum brain-derived neurotrophic factor concentrations in lean and overweight children and adolescents. J Clin Endocrinol Metab 2006;91:3548-52.

Cite this article as: Lee KW, Ching SM, Devaraj NK, Hoo FK. Genetic polymorphisms in neuroendocrine disorderrelated candidate genes associated with pre-pregnancy obesity in gestational diabetes mellitus patients by using a stratification approach. Ann Transl Med 2020;8(17):1060. doi: 10.21037/atm20-1579
57. Lyons WE, Mamounas LA, Ricaurte GA, et al. Brainderived neurotrophic factor-deficient mice develop aggressiveness and hyperphagia in conjunction with brain serotonergic abnormalities. Proc Natl Acad Sci 1999;96:15239-44.

58. Friedel S, Fontenla Horro F, Wermter A, et al. Mutation screen of the brain derived neurotrophic factor gene (BDNF): identification of several genetic variants and association studies in patients with obesity, eating disorders, and attention-deficit/hyperactivity disorder. Am J Med Genet B Neuropsychiatr Genet 2005;132B:96-9.

59. Akkermann K, Hiio K, Villa I, et al. Food restriction leads to binge eating dependent upon the effect of the brainderived neurotrophic factor Val66Met polymorphism. Psychiatry Res 2011;185:39-43.

60. Gunstad J, Schofield P, Paul RH, et al. BDNF Val66Met polymorphism is associated with body mass index in healthy adults. Neuropsychobiology 2006;53:153-6.

61. Shugart YY, Chen L, Day IN, et al. Two British women studies replicated the association between the Val66Met polymorphism in the brain-derived neurotrophic factor (BDNF) and BMI. Eur J Hum Genet 2009;17:1050. 
Table S1 Analyses of the LHPP, SDK2, TEX51, EPHX2, NPY 5R and ANO2 genotypes among the GDM patients with and without obesity (n=312)

\begin{tabular}{|c|c|c|c|c|c|c|c|c|}
\hline \multirow{2}{*}{$\begin{array}{l}\text { Candidate } \\
\text { genes }\end{array}$} & \multirow[b]{2}{*}{ SNP } & \multirow[b]{2}{*}{ Genotype } & \multicolumn{3}{|c|}{ Asian criteria-based BMI } & \multicolumn{3}{|c|}{ International criteria-based BMI } \\
\hline & & & $\begin{array}{c}\text { Normal and } \\
\text { Overweight }(n=122)\end{array}$ & Obese $(n=190)$ & $P$ value & $\begin{array}{c}\text { Normal and } \\
\text { Overweight }(n=174)\end{array}$ & Obese $(n=138)$ & $P$ value \\
\hline \multirow[t]{7}{*}{ LHPP } & rs35936514 & $\mathrm{CC}$ & $57(47.1)$ & $95(50.0)$ & 0.642 & $85(49.1)$ & $67(48.6)$ & 0.617 \\
\hline & & CT & $50(41.3)$ & $79(41.6)$ & & 69 (39.9) & $60(43.5)$ & \\
\hline & & TT & $14(11.6)$ & $16(8.4)$ & & $19(11.0)$ & $11(8.0)$ & \\
\hline & & CC genotype & $57(47.1)$ & $95(50.0)$ & 0.619 & $85(49.1)$ & $67(48.6)$ & 0.919 \\
\hline & & T carrier & $64(52.9)$ & $95(50.0)$ & & $88(50.9)$ & $71(51.4)$ & \\
\hline & & C carrier & $107(88.4)$ & $174(91.6)$ & 0.359 & $154(89.0)$ & $127(92.0)$ & 0.371 \\
\hline & & TT genotype & $14(11.6)$ & $16(8.4)$ & & $19(11.0)$ & $11(8.0)$ & \\
\hline \multirow[t]{7}{*}{ SDK2 } & rs3816995 & GG & $74(61.2)$ & $113(59.5)$ & 0.793 & $100(57.8)$ & $87(63.0)$ & 0.642 \\
\hline & & GA & $41(33.9)$ & $64(33.7)$ & & $62(35.8)$ & 43 (31.2) & \\
\hline & & AA & $6(5.0)$ & $13(6.8)$ & & $11(6.4)$ & $8(5.8)$ & \\
\hline & & GG genotype & $74(61.2)$ & $113(59.5)$ & 0.768 & $100(57.8)$ & $87(63.0)$ & 0.348 \\
\hline & & A carrier & $47(38.8)$ & $77(40.5)$ & & 73 (42.2) & $51(37.0)$ & \\
\hline & & G carrier & $115(95.0)$ & 177 (93.2) & 0.499 & $162(93.6)$ & $130(94.2)$ & 0.837 \\
\hline & & AA genotype & $6(5.0)$ & $13(6.8)$ & & $11(6.4)$ & $8(5.8)$ & \\
\hline \multirow[t]{7}{*}{ TEX51 } & rs6733840 & TT & 76 (62.3) & $118(62.1)$ & 0.578 & $108(62.1)$ & $86(62.3)$ & 0.669 \\
\hline & & $\mathrm{TC}$ & $42(34.4)$ & $61(32.1)$ & & $56(32.2)$ & $47(34.1)$ & \\
\hline & & $\mathrm{CC}$ & $4(3.3)$ & $11(5.8)$ & & $10(5.7)$ & $5(3.6)$ & \\
\hline & & TT genotype & $76(62.3)$ & $118(62.1)$ & 0.973 & $108(62.1)$ & $86(62.3)$ & 0.964 \\
\hline & & C carrier & $46(37.7)$ & 72 (37.9) & & 66 (37.9) & $52(37.7)$ & \\
\hline & & T carrier & $118(96.7)$ & 179 (94.2) & 0.312 & 164 (94.3) & $133(96.4)$ & 0.384 \\
\hline & & CC genotype & $4(3.3)$ & $11(5.8)$ & & $10(5.7)$ & $5(3.6)$ & \\
\hline \multirow[t]{7}{*}{ EPHX2 } & rs17466684 & GG & 95 (77.9) & $141(74.2)$ & 0.758 & 132 (75.9) & $104(75.4)$ & 0.946 \\
\hline & & $\mathrm{GA}$ & $24(19.7)$ & $44(23.2)$ & & $38(21.8)$ & $30(21.7)$ & \\
\hline & & $A A$ & $3(2.5)$ & $5(2.6)$ & & $4(2.3)$ & $4(2.9)$ & \\
\hline & & GG genotype & 95 (77.9) & $141(74.2)$ & 0.463 & 132 (75.9) & $104(75.4)$ & 0.919 \\
\hline & & A carrier & $27(22.1)$ & 49 (25.8) & & $42(24.1)$ & $34(24.6)$ & \\
\hline & & G carrier & 119 (97.5) & 185 (97.4) & 1.000 & $170(97.7)$ & $134(97.1)$ & 0.736 \\
\hline & & AA genotype & $3(2.5)$ & $5(2.6)$ & & $4(2.3)$ & $4(2.9)$ & \\
\hline \multirow[t]{7}{*}{ NPY5R } & rs12501691 & $\mathrm{TT}$ & $82(67.2)$ & $132(69.5)$ & 0.849 & $116(66.7)$ & $98(71.0)$ & 0.640 \\
\hline & & TA & 38 (31.1) & $54(28.4)$ & & 55 (31.6) & $37(26.8)$ & \\
\hline & & $\mathrm{AA}$ & $2(1.6)$ & $4(2.1)$ & & $3(1.7)$ & $3(2.2)$ & \\
\hline & & TT genotype & $82(67.2)$ & $132(69.5)$ & 0.675 & $116(66.7)$ & $98(71.0)$ & 0.411 \\
\hline & & A carrier & $40(32.8)$ & $58(30.5)$ & & $58(33.3)$ & $40(29.0)$ & \\
\hline & & T carrier & $120(98.4)$ & $186(97.8)$ & 1.000 & 171 (98.3) & 135 (97.8) & 1.000 \\
\hline & & AA genotype & $2(1.6)$ & $4(2.1)$ & & $3(1.7)$ & $3(2.2)$ & \\
\hline \multirow[t]{7}{*}{ ANO2 } & rs12579350 & GG & $106(86.9)$ & $164(86.3)$ & 0.975 & $150(86.2)$ & $120(87.0)$ & 0.677 \\
\hline & & GA & 15 (12.3) & 24 (12.6) & & 23 (13.2) & 16 (11.6) & \\
\hline & & $\mathrm{AA}$ & $1(0.8)$ & $2(1.1)$ & & $1(0.6)$ & $2(1.4)$ & \\
\hline & & GG genotype & $106(86.9)$ & $164(86.3)$ & 0.886 & $150(86.2)$ & $120(87.0)$ & 0.847 \\
\hline & & A carrier & $16(13.1)$ & $26(13.7)$ & & $24(13.8)$ & $18(13.0)$ & \\
\hline & & G carrier & $121(99.2)$ & 188 (98.9) & 1.000 & $173(99.4)$ & $136(98.6)$ & 0.586 \\
\hline & & AA genotype & $1(0.8)$ & $2(1.1)$ & & $1(0.6)$ & $2(1.4)$ & \\
\hline
\end{tabular}

